\title{
UNCLASSIFIED
}

BNWL-1149

UC-48

$2-$

$7-69$

\section{PACIFIC NORTHWEST LABORATORY MONTHLY ACTIVITIES REPORT} FOR JUNE 1969

DIVISION

OF

BIOLOGY AND MEDICINE

PROGRAMS

July 1969

\section{AEC RESEARCH \& DEVELOPMENT REPORT}

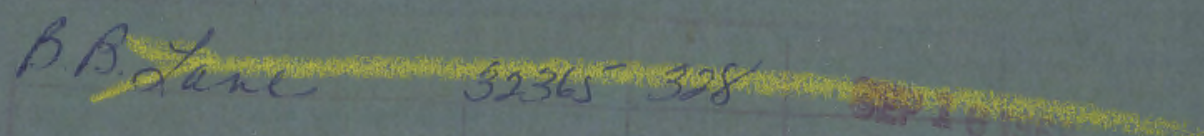




\section{LEGAL NOTICE}

This report was prepared as an account of Government sponsored work. Neither the United States, nor the Commission, nor any person acting on behalf of the Commission:

A. Makes any warranty or representation, expressed or implied, with respect to the accuracy, completeness, or usefulness of the information contained in this report, or that the use of any information, apparatus, method, or process disclosed in this report may not infringe privately owned rights; or

B. Assumes any liabilities with respect to the use of, or for damages resulting from the use of any information, apparatus, method, or process disclosed in this report.

As used in the above, "person acting on behalf of the Commission" includes any employee or contractor of the Commission, or employee of such contractor, to the extent that such employee or con. tractor of the Commission, or employee of such contractor prepares, disseminates, or provides access to, any information pursuant to his employment or confract with the Commission, or his employment with such contractor.

\section{PACIFIC NORTHWEST LABORATORY}

RICHLAND, WASHINGTON

operated by

BATTELLE MEMORIAL INSTITUTE

for the

UNITED STATES ATOMIC ENERGY COMMISSION UNDER CONTRACT AT(45-1)-1830 


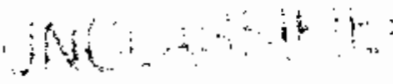

BNTL - 1149

UC -48

Biology and Medicine
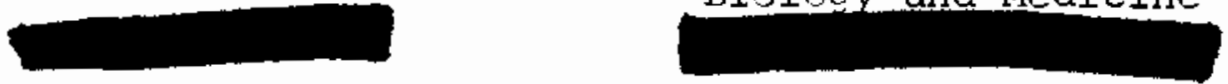

PACIFIC NOPTHTEST IAABORATORY

MONTHLY ACTIVITIES REPORI

JUNE 1969

Division

of

Biology and Medicine

Programs

by the

Staff of Battelle-Northwest

F. W. Albaugh, Director

July 1969

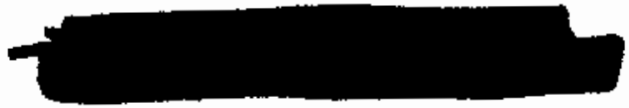

BATTELLE MEMORIAL INSTITUTE

PACIFIC NORTHWEST LABORATORY RICHLAND, WASHINGTON

99352

INCLASSIFIED 


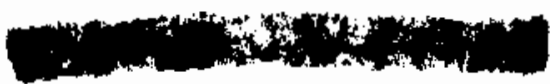

2.

BNWL - 1149

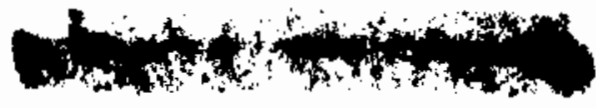

Printed in the United States of America Available from

Clearinghouse for Federal Scientific and Technical Information National Bureau of Standards, U.S. Department of Commerce Springfield, Virginia 22151

Price: Printed Copy $\$ 3.00 ;$ Microfiche $\$ 0.65$ 


\title{
PACIFIC NORTHWEST LABORATORY
}

\author{
MONTHLY ACTIVITIES REPORT
}

JUNE 1969

\author{
ATOMIC ENERGY COMMISSION \\ DIVISION OF BIOLOGY AND MEDICINE PROGRAMS - EDWARD L. ALPEN
}

\section{TOXICITY OF RADIOELEMENTS}

Metabolism and Effects of Radionuclides in the Developing Fetus and the Young - M. F. Sullivan

Preliminary experiments indicate that differential dialysis will selectively chelate specific zinc pools in liver and muscle. Liver and muscle were chosen as representative tissues to explain possible subtle differences in the binding of $65 \mathrm{zn}$ by tissues of the mature and immature rat. These tissues are being dialyzed against chelating agents having different stability constants for the zinc-chelating agent complex. Quantitative data will define the zinc pools on an age-related basis.

Effects of Radiostrontium in Miniature Swine - W. J. Clarke

Three of the four animals in the $313 \mu \mathrm{Ci} 90 \mathrm{sr} /$ day group farrowed this month. Litter size ranged from five to eight pigs per litter, well within the normal limits for control swine of this breed. Platelet values continue to decline in these sows.

The second of four Hanford Miniature swine receiving 625 $\mu \mathrm{Ci} 90^{\mathrm{Sr}} / \mathrm{day}$ was sacrificed after 20 months' feeding following an extended period of anorexia. Although peripheral blood values were not considered to be at a critical level, extensive skeletal erosion and necrosis were observed at necropsy. Four Pitman-Moore swine at this feeding level were all dead after 17 months' feeding; two of four Hanford Miniatures are still alive after 20 months' feeding.

$$
\text { Inhalation Studies - J. F., Park }
$$

Plutonium analyses were completed on tissues from a beagle dog sacrificed due to respiratory insufficiency and radiographic evidence of pulmonary neoplasia $61 / 2$ years after inhalation of $239 \mathrm{PuO}_{2}$ aerosols. The body burden at death was $0.7 \mu \mathrm{Ci}$ with 15 percent of the plutonium in the lungs, 40 percent in the tracheobronchial and mediastinal lymph nodes, 32 percent in the liver, 7 percent in the skeleton, 3 percent in the pancreas, and 1 percent in the spleen. At necropsy multiple 
tumors were observed in the lungs. Histopathology is not yet compleie. Another dog on this long-term study was kilied with similar clinical signs and gross pathology 7 years postexposure. Plutonium analysis and histopathology are in progress. To date, 19 of 40 dogs exposed to $239 \mathrm{PuO}_{2}$ aerosols have shown pulmonary neoplasia at death 3 to 8.5 years postexposure. Of the elght surviving dogs, now 7 to 9 years postexposure, five show radiographic evidence of pulmonary neoplasia.

Histopathology was completed on all dogs sacrificed up to $31 / 4$ years after inhalation exposure to ${ }^{106} \mathrm{Ru}-106 \mathrm{RhO}_{2}$ aerosols

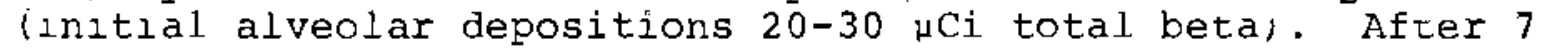
months, virtually all of the total body burden was found in the lungs, causing diffuse septal cell proliferation, early parenchymal consolidation and early fibrosis. At $31 / 4$ years postexposure, effective decay had reduced lung dose rates to $1 / 10$ of initial, and lung pathology in dogs sacrificed at this time consisted of some congestion, and thickening and edema of the interalveolar septa. Early connective tissue infiltration was also found. Thus, lung changes at $31 / 4$ years were not significantly greater than those at $1 / 2$ year, when much higher dose rates prevalled; some degree of recovery may have occurred. Although the tracheobronchial lymph nodes increased from 3\% to $11-178$ of total body burden at 2 years and $31 / 4$ years after exposure, damage seems about the same, i.e., moderate lymphoid hyperplasia; therefore, this tissue also shows no increase in severity of damage with time.

Histopathology was completed on seven rats (two controls and flve experimentals) following intrathoracic injection of $1.0, \mathrm{Cl}_{1} 239 \mathrm{PuO}_{2}$ particles into the lung. No pulmonary carcinomas were seen in controls, although pulmonary adenomas were seen in one control. In the $239 \mathrm{pu}$ injected rats, one bronchiolar carcinoma in situ was seen at 185 days; one endothelloma in the lung was seen at 283 days; and no tumor was seen in one rat at 285 days. Two rats killed at 314 and 315 days postinjection showed gross evidence of pulmonary neoplasia.

Additional experiments were completed studying the therapeutic removal of inhaled $239 \mathrm{PuO}_{2}$ from rat lungs employing the drugs Diamox, Diuril, and Miltown. None of the results were promising. Increasing the dose of drug three-fivefold decreased the efficiency of removal. Some enhancement of removal was obtalned by treating the animals with DTPA in addition to the drug. DTPA was ineffective when given alone.

$$
\frac{\text { Inhalation Hazards to Uranium Miners, }}{\text { Biological Studies - J. F. Park }}
$$

Dally exposures of hamsters to radon plus daughters and uranium ore dust continued. 
A positive seal for radon chamber individual dog ports has been designed. A dome-shaped chamber filter has been tested to channel air flow past the dogs' muzzles; this was also found to reduce humidity build-up problems over 4-hour exposures.

Inhalation Hazards to Uranium Miners, Radiochemical Studies - N. A. Wogman

The alpha spectrometry diode and sodium iodide crystal for the development of the continuous radon daughter analyzer are being assembled and evaluated. During this continuing evaluation, radon from the test cells of radon inhalation experiments and mine atmospheres will be analyzed. This continuous radon analysis is capable of measuring radon daughter concentrations versus particle size employing both alpha- and gama-ray spectrometry. The system provides measurement of the radon daughter concentrations of $214 \mathrm{po}, 214 \mathrm{Bi}, 214 \mathrm{pb}$, and $218 \mathrm{po}$.

Internal Deposition of Radionuclides

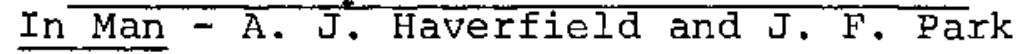

The prototype tissue monitor installed in the hospital autopsy facility was placed in operation and taking of background measurements was begun.

A literature search was initiated and study begun to elucidate in depth the present state of dosimetry of alpha-emitting radionuclides in the human lung. The objective of this activity is to improve confidence in assessment of dose from alphaemitting contaminants in both in vivo promethium oxide and plutonium studies. Results of this work may also find use in clarifying lung dosimetry of uranium miners.

MOLECULAR AND CELLULAR LEVEL STUDIES

Characterization of Radiation-Induced Free Radical Reactions in Aqueous Systems - A. J. Haverfield

Chemical-reducing capabilities of radicals derived from hydroxyl-radical attack on cystine, threonine and methionine were examined by ESR measurements on aqueous solutions in the irradiated flow system. Only the radical derived from methionine was found able to reduce p-nitrobenzoate to its radicalanion; but this reaction proceeded very efficiently, surpassing even those initiated by radicals derived from methanol and ethanol.

Capabilities of biochemical radicals in initiating polymerization were also tested. Dry samples of polycrystalline substances containing approximately $5 \times 1018$ radicals were dissolved in $3 \mathrm{~m} 1$ of $5.0 \mathrm{M}$ acrylamide. Radicals derived from 
lactose, galactose, glucose, mannose, glycine and a-alanine produced firm polyacrylamide gels while radicals derived from fructose, arabinose and mannitol were without effect. control experiments showed that polymerization could not be initiated by non-irradiated samples of any of the substances and irradiated samples lost this ability shortly after dissolution in water.

\section{ENVIRONMENTAL RADIATION STUDIES}

Project ALE, Administrative Summary - D. W. Pearce

Extensive repair and stabilization of the ALE dirt road network proceeded on schedule and is expected to extend over into Fiscal Year 1970 while the machinery is on the site.

The $\$ 250,000$ project proposal for partial refurbishment of the Ecology Headquarters Building was not approved by RL for FY-1969. Minor work on the Small Animal Quarters Building, however, will permit its occupancy by five or six scientrsts within eariy FY-1970.

\section{$\frac{\text { Geology and Paleoecology of the ALE Reserve - }}{\text { K. R. Price }}$}

Field work on Gable Mountain* and at Rattlesnake Springs continued to provide data correlatable between the two sites on the early Holocene history of the Pasco Basin. Numerous thin layered flood deposits at an altitude of about 700 feet on both sites are associated with the Glacier Peak ash bed which indicates their contemporaneity. Their similar altitudes and physiographlc features indicate that the basin fill stood for some time at about 700 feet MSL in the northern part of the Hanford area and extended nearly to North Richland. At west Richland ice-rafted erratics abundant at 700 feet MSL suggest the IImit of basin fill there. Southward, the narrowing basin caused flood waters to flow more rapidly to the wallula Gap base level and precluded deposition of sediments at comparable altitudes.

Subsequent lesser floods across the plateau resulted in downcutting of the northern part of the Ringold coulee to 600 feet MSL and erosion of the fill over much of the Hanford area to similar levels. The time probably was between 10,000 and 11,000 years ago corresponding with the last period of coulee excavation and may have been contemporaneous with the last occupancy of the Lind coulee area by early man. Sometime subsequentiy the coulees became dry water courses unsuitable for habitation.

* Not charged to the Division of Blology and Medicine 
By 10,000 years ago or less the fill was eroded adjacent to 100-N Area to an altitude of about 475 feet. This presently is indicated by knob and kettle topography. Additional erosion by the more normal Columbia River has resulted in a farther eastward shift and lowered stream bed.

The above events indicate that the longitudinal sand ridges traversing the Hanford Project area from the ALE Reserve (the junction of Cold and Dry Creek Valleys) to the area south of old Hanford townsite must be solely eolian in origin. They traverse benches or terraces which were erosional in origin and cut at different times. The mechanics of their origin have yet to be fully determined for they differ from currently migrating dunes. They reflect Altithermal and immediate post-Altithermal climates and wind patterns.

$$
\frac{\text { Hydrology of the ALE Reserve - }}{\text { K. R. Price }}
$$

The results from routine sampling of surface waters on the ALE Reserve at Snively Canyon and Rattlesnake Springs are continuing to characterize these areas. Conductivity, dissolved oxygen, and $\mathrm{pH}$ have tended to remain constant since early April. Water temperatures of springs have decreased slightly since mid-May, whereas stream water temperatures increased until the last part of June when they decreased in response to cooler air temperatures. Conductivity- and temperaturedistance profiles for single points in time indicate that four major sources of water probably exist in the Rattlesnake Springs portion of Dry Creek. The most upstream of these sources appears to enter the stream from a different aquifer than downstream seeps. A similar study in the Snively Canyon area points toward a more complex hydrogeology than at Dry Creek. At Snively an unresolved temperature anomaly of $2.5^{\circ} \mathrm{C}$ was noted between two springs approximately 200 feet apart. An additional complication also at Snively is the fact that stream flow starts and stops three times over a distance of 5,000 feet.

Three more hand-augered piezometer tubes were installed within the greasewood community at Rattlesnake Springs. In addition to this type of piezometer, which permits the use of a neutron probe moisture meter, four smaller piezometers constructed of $3 / 8$ inch galvanized pipe were installed. The small diameter pipe was pounded into the ground at one location to a depth of $10 \mathrm{~m}$ and appears to be a satisfactory way of monitoring perched water table fluctuations. The rate of recession of the perched water table has decreased apparently in response to cooler temperatures and expected slower transpiration rates. The flow of the Rattlesnake springs stream has remained steady despite fluctuations and a lowering of the perched water table since March. 
Soll Relationships - K. R. Price

The laboratory study on the degradation of Poa tissue in warden soil was terminated. Results from the completed study are being analyzed and evaluated.

Ecological Micrometeorology and Climatology of the ALE Reserve - K. R. Price

Plant growth and phenology continue to be observed during routine traverses of the microclimatological network.

$$
\text { Computer Data Display System* - R. T. Jaske }
$$

Certain portions of the display executive were coded.

The UNIVAC 1558 display was received. A complete electrical inspection will be performed as soon as the interface is completed.

The disc memory unit purchase contract was sent to Digital Development Corporation April 17. DDC has indicated a midSeptember or early-October delivery.

Installation and debugging of the Extended Arithmetic Element for the PDP 9 has been completed and this option is now operational. The Multilevel Priority Interrupt has been installed and is now in the process of being debugged.

\section{Terrestrial Ecology}

Terrestrial Plant Ecology - T. P. O'Farrell

The harvest yield of vegetation from abandoned cultivated fields at three different elevations was completed. Selected specles are currently being analyzed for macronutrients, nitrogen, phosphorus, potassium, calcium, magnesium, and certain micronutrient elements.

The yleld at the highest elevation (1700 feet) averaged only $225 \mathrm{~g} / \mathrm{m}^{2}$. This yield is considerably lower than that reported earlier for fields located at 600 feet and 1000 feet, l.e., 380 and $306 \mathrm{~g} / \mathrm{m}^{2}$. The low yield at the high elevation cannot be attributed to soil drought because soil moisture was more abundant there than at the other sites. The low yield may be attributable to a paucity of some essential nutrient or nutrients and this is being investigated.

* In part also charged to the AEC Divisions of Production and of Reactor Development and Technology 
The 1969 harvest yield probably represents the maximum yield for this kind of vegetation in this region. According to local ranchers, the 1969 forage yield was the best in the last 20 years.

The 1968 harvest yield, grown during one of the driest climatic years on record, produced about $80 \mathrm{~g} / \mathrm{m}^{2}$ at the 1000 and 1200 foot elevations. From these data, it can be expected that the average annual yield (net primary production of aboveground parts) will range between the two values reported here.

The abnormally high soil moisture early this spring also resulted in an increase in cheatgrass infected with a "head smut." This smut was identified as being Ustilago bullata Berk, a head smut which is ubiquitous from British columbia, south to Arizona, and east as far as North Dakota. This disease often destroys a high percentage of the seed of this grass. The environmental requirements of this disease closely follow those which favor a high seed production in $\mathrm{B}$. tectorum.

A check was made to determine the percent seed loss which occurred this season on the ALE Reserve. Three transect lines were made through the reservation. The average percent infection ranged between $4.7 \%$ and $36.6 \%$, with an average of $18 \%$.

With the high yield of seeds this year, it seems highly unlikely that there will be any reduction in $\mathrm{B}$. tectorum because of this disease unless we experience several successive moist springs.

Terrestrial Animal Ecology - T. P. O'Farrell

Trapping success on the small mammal study area remained high during the month. However, the age composition of the catch changed drastically as the first litters of pocket mice entered the trappable population. Over $65 \%$ of the mice are juvenals, many weighing less than $10 \mathrm{~g}$. It appears that the rate of disappearance of the adults was much greater this year but further comparisons between previous data will be required to substantiate this. For the first time, we have observed small juvenals in breeding condition, and no doubt they will contribute to the reproductive success this summer.

Analyses of the population dynamics of the small mammals performed by the Mathematics Department have led to improvements in trapping techniques on the plots. Past data indicated that prebaiting traps for at least one night before trapping might improve success, and that setting 400 traps at least once every other week would improve estimates of the population size. It is hoped the close working relationship between the departments will lead to further refinements in the quantification of 
the ecological studies, as well as stimulating theoretical studies of fundamental population dynamics.

A computer program was completed to calculate and graphically describe the home ranges of the various species of small mammals. Among other things, the output includes the center of activity, radius of movements, tests of correlations between movements, variability, and both circular and elliptical approximations of range area, both in metric and English units. Preliminary data indicate that most pocket mice have ranges that can be estimated using a circle, while grasshopper mice and deer mice have ranges which are longer than they are wide. Most of the deer mouse ranges are aligned in an east-west direction but aerial photos do not suggest any gross vegetation or soll anomaly which might influence range shapes.

Systems Analysıs and Environmental Data Center - T. P. O'Farrell

Study of uptake and retention models has largely been devoted to simulating a set of data on radio-labeled DDT in a fresh-water marsh. The models are very much the same as those used in the Alaskan and Scandinavian food-chaln studies and they also employ the DYNAMO computer language. The basic unit is a difference equation corresponding to the usual uptake-andretention input-output differencial equation, and the major problems have to do with choice of functions for input terms and estimation of constants. In the actual study (conducted in Ohıo in 1964-65), DDT was applied in granular form (by helicopter) and the bulk of the release seems to have occurred from granules on the bottom of the marsh laverage water depth was about one foot). After trying various possibilities, we have assumed that the input function follows a decreasing exponential curve, as is also the case in many situations involving radionuclides. Non-linear least squares methods have been used to estimate coefficients for the model representing levels in (filtered) water:

$$
y=\frac{\lambda}{k-\mu}\left[e^{-\mu t}-e^{-k t}\right]
$$

where:

$$
\begin{aligned}
& \lambda=\text { inltial release rate (from granules) } \\
& k=\text { release rate (granules) } \\
& i=\text { loss rate (from water) and } \\
& t=\text { time (from DDT application). }
\end{aligned}
$$

We initially assumed $k:$ in, but this ylelds an unreasonably low total quantity of DDT released to water, so that it seems rather more realistic to take $i \Rightarrow k$. The functional form of the 
equation remoins unchan ed ibeyord a change of sign), so the least-squares estimates are unchanged. Initial results frr tiee least-squares fit are (in ppb DDT):

\begin{tabular}{ccc} 
Time (Hours) & Observed & Fixpected \\
\hline 6 & 0.3 & 0.77 \\
8 & 0.9 & 0.95 \\
12 & 1.2 & 1.19 \\
18 & 1.3 & 1.26 \\
120 & 0.3 & 0.48 \\
720 & 0.4 & 0.24 \\
168 & 0.0 & 0.0
\end{tabular}

Two points were excluded on the basis of being very much removed from the calculated curve; there is a prospect that problems with filtering out suspended matorial and adhering of DNT to (plastic) container walls may have been responsible.

Mathematical Simulation of Radionuclide Transfer and Food Chain Process - T. P. O'Farrell

The computer simulation model of $137 \mathrm{Cs}$ in the Scandinavian Arctic has been modified to correct difficulties of synchronization of inputs. Computed concentrations in both lichens and reindeer approximate those actually observed. The simulated values for Lapps are too high, suggesting that reported quantities of reindeer meat eaten are overestimated, much as was found in the Alaskan system.

\section{Aquatic Ecology}

Ecological Characteristics of the Columbia River - W. L. Tenpleton

The fourth sampling is completed, representing the river at peak flow. A fifth sampling will be made at normal summer flows to complete the annual cycle.

Initial examination of the suspended materials shows that the bulk falls within the 53 to $2.0 \mu$ silt size range. Samples of all isolated fractions have been preserved for biological observation and should provide a basis for estimation of the contribution of algae cells to the larger-size fractions. However, 20-308 of the particulates were of clay size, i.e., less than $2.0 \mu$. Furthermore, $16 \%$ and $7{ }^{\circ}$ of the suspended material in 
the fall and winter samplings, respectively, have particle diameters of less than $0.5 \mu$. The less than $0.5 \mu$ materials are often erroneously referred to as "soluble," whereas, in fact, they are colloidal particles which normally exhibit relatively high surface areas and charge densities. Consequently, they may exert strong influences on the behavior of ions soluble in river water. It is expected that the spring samplings of Columbia River water will contain proportionately larger quantities of highly reactive materials less than $2.0 \mu$ in diameter. Removal of organic materials complexed with suspended minerals may also result in a proportionate increase in the quantities of particulates present in the smaller-size fractions.

Seasonal differences in particulate size distribution were not pronounced, but measurements indicated an increase of approximately 98 in the 53 to $2.0 \mu$ fraction from November, 1968 , to February, 1969. This increase was accompanied by a corresponding decrease in the smaller-size fractions.

Presently, the clay mineral composition and ion exchange capacity of the isolated fractions are being elucidated. The research will then be directed toward (a) measurement of the relative contribution of the mineral and organic fractions to ion exchange reactions and (b) determination of the influence of river $\mathrm{pH}$ and temperature on the relative bond strength of ions of different valence to particulate functional groups.

The plankton pumping equipment was moved to the barge anchored near $100-F$ in preparation for investigation of the annual cycles of plankton biomass.

Rates and Mechanisms of Biogeochemical Processes of the Columbia River - W. I. Templeton

Zinc-65 Cycling by Periphyton. The slide transfer experiment to determine retention of zinc-65 was terminated before conclusion, when analyses showed no measurable zinc-65 in any of the sequential samples, including the pre-transfer sample. This unusual situation is probably the result of three things: low radiozinc levels because of dilution by runoff, (2) rapid removal of the zinc-65 by adsorption to the high silt load present at the time the slides were exposed, and (3) channeling of the reactor effluent plumes to the west side of the river during high flows - the slides were on the east side.

A series of laboratory experiments to determine the effect of competing stable cations on the zinc-65 uptake rates was initiated. The first test was conducted with normal stable $z i n c$ concentration spiked with $10 \mathrm{ki} \mathrm{zinc}-65$, This is our usual spike level and the resulting uptake curve was "normal" with apparent equilibrium at about 40 hours. The second run is in 
progress and contains approximately two times the normal stable zinc concentration (in atoms) spiked with $10 \mu \mathrm{Ci}$ zinc-65.

Modeling of Phytoplankton Populations in the columbia River. Preliminary analysis of phytoplankton populations to develop equations to account for some of the environmental parameters in the Columbia River has been completed. The parameters include solar radiation at the surface, attenuation by reflectance, photosynthesis, respiration and death rate of phytoplankton, temperature, and rate of change of plankton concentrations. The analysis also contains a preliminary block diagram of the possible relations existing among the ecosystem components.

Work now being done involves an evaluation of the analysis for completeness at this stage, and providing data concerning seasonal fluctuations and turnover rates of the two or three dominant species we are interested in. Some of the numbers are available from the 1962 studies, but data on turnover rates, etc., are available only in the literature and usually for lentic populations. It will take some time and thought to provide meaningful data to apply to the river situation.

Effects of Modifications on the Columbia River Ecosystem W. L. Templeton

Thermal Modifications. Six experimental stream channels are being established for growing periphyton communities at four increments of $2.5^{\circ} \mathrm{C}$ above river temperature. One channel is covered with a light box to regulate photoperiod. The apparatus is nearly operational; initiation of studies is expected in early July.

Initial steps have been taken toward resuming studies of the effects of thermal shock on relative predation rates of juvenile salmonids. Statistical analyses completed in June on data obtained in 1968 indicated directions for further study. A preliminary report is in preparation.

Biweekly samples of invertebrate drifts were discontinued in mid-June. Samples are now available for subsequent analysis over a two-month period in the spring of 1969. These collections are deemed sufficient for quantitative and qualitative assessment of invertebrate drift above and below the Hanford reactor discharges during this period, in correlation with ambient water conditions which prevailed. Superficial examination of the samples indicates lower quantities of zooplankton in late May and June than in April and early May. This presumably reflects the flushing of winter concentrations of zooplankton from Priest Rapids reservoir with spring runoff in the columbia River. 
Plans call for additional samples to be collected for a two-month period in late summer and fall, for evaluation and comparison with the spring samples.

Radiation Regimes. TLD (LIF powder) dosimeters implanted In 16 Canada goose eggs and kept under refrigeration during exposure gave a mean dose rate of $0.8 \mathrm{mR} / \mathrm{day}$ (essentially background) with a range of 0.6 to 1.4. This is about one half the dose rate measured in the goose nests in the natural environment.

Dosimeters were placed at 3 locations labove 100-B, opposite 100-D and below 100-F Area) to measure relationship of dose wlch proximity to $100-\mathrm{K}$ effluent outfalls. At each location, measurements will be made at the bottom of the river, at approxlmately 5,10 and 15 feet from the bottom, and just below the surface.

Surface water doses measured near 100-F Area were 9.6 $\mathrm{mR} / \mathrm{day}$ for the perıod $3 / 23 / 69$ to $6 / 12 / 69$ (81 days). This rate is slightly less than the observed dose rate of $7.5 \mathrm{mR} / \mathrm{day}$ for the period $3 / 23 / 69$ to $4 / 15 / 69$ (24 days): This would seem to indicate there was no decrease in the dose rate from water durlng the freshet period.

Radionuclides in the Alaskan Environment

Rates of Deposition of Alrborne Radionuclides in the Alaskan Environment - N. A. Wogman

Chum salmon obtaıned near Kotzebue, Alaska, from two separate runs of July 10 and August 15, 1968, showed distinct differences in radionuclide concentration. The radionuclides $54 \mathrm{Mn}, 55 \mathrm{Fe}$, and $60 \mathrm{Co}$ are about threefold higher in concentration in the early run, while $137 \mathrm{Cs}$ concentrations are fairly constant between runs. Zinc-65 concentrations are highest in the last run, lndicating that the salmon feed farther south than the early run and are affected to a greater extent by the $65 \mathrm{z}_{\mathrm{n}}$ from the Columbia Rıver. During the last one-year period, all salmon that have been analyzed from the California Paclfic Coast to Kotzebue, Alaska, have contained some $65 \mathrm{zn}$, indicating the Columbia River influence.

\section{MARINE SCIENCES}

$\frac{\text { Physical and Radlological Chemistry }}{\text { of Ocean Solutions - N. A. Wogman }}$

Typlcal oceanic concentrations of the trace elements Sr, $\mathrm{Cs}, \mathrm{U}, \mathrm{Sb}, \mathrm{Co}, \mathrm{Sc}, \mathrm{Zr}, \mathrm{Fe}, \mathrm{Cu}$, and $\mathrm{Mn}$ in surface waters collected in the Central Pacific, Mediterranean Sea, Columbia River estuary, and near the cost of Monaco have been determined. 
Cobalt concentrations in the Central Pacific ocean averaged about $0.01 \mu \mathrm{g} / 1 \mathrm{with}$ a range of from 0.0018 to $0.050 \mu \mathrm{g} / 1$. These concentrations are approximately one-hundredth of earlier reported values for this area of the ocean. It appears that earlier measurements were severely contaminated with co sometime during their collection or subsequent analysis by the earlier investigators. Interlaboratory comparisons between

Battelle-Northwest and the International Laboratory of Marine Radioactivity are in excellent agreement. Manganese and copper concentrations which were measured in the central Pacific ocean by solvent extract and neutron activation averaged 0.056 and $0.64 \mathrm{\mu g} / 1$, respectively. The $\mathrm{Cu}$ concentrations are typical of ocean water; however, the manganese values are about one-tenth of the concentrations reported in the Atlantic ocean and the Gulf of Mexico. It appears that the Central Pacific ocean is relatively deficient in trace elements such as $\mathrm{Co}, \mathrm{Mn}$, Fe, and Sc. This may be a partial explanation for the "marine desert" conditions existing in the area. The long resident time of ocean waters in isolation from land masses may diminish the trace elemental content of elements such as $\mathrm{Co}, \mathrm{Mn}, \mathrm{Fe}$, and $\mathrm{Sc}$ through biogeochemical precipitation reactions.

A joint Battelle-Northwest/Oregon State University investigation of the absolute and relative transport and mixing rates of the Columbia River radionuclides at sea was started. The river radionuclides which will be used are $5 l_{C r}, 226-228 \mathrm{Ra}$, and several fallout and additional Columbia River radionuclides. Information is also being obtained on the physical and chemical forms of the radionuclides and their changes with time.

\section{ATMOSPHERIC RADIOACTIVITY AND FALLOUT}

\section{Fallout Studies}

Radioactive Fallout Rates and Mechanisms - N. A. Woaman

The concentrations of radon daughter products were measured in air at altitudes of $10,000,17,000$, and 23,000 feet. Samples were collected by filtering the daughter products from air using IPC filter media and the concentrations of $214 \mathrm{Bi}$ were $6.17 \mathrm{dis} / \mathrm{min} / \mathrm{m}^{3}, 10.28 \mathrm{dis} / \mathrm{min} / \mathrm{m}^{3}$, and $11.73 \mathrm{dis} / \mathrm{min} / \mathrm{m}^{3}$, respectively. A comparison of these data to the radon concentrations which wore determined simultaneously by the Health and Safety Laboratory indicates that the latter's radon procedure must be modified to inhibit the deposition of radon on collection piping materials. The concentrations of the medium-level radionuclides $95 \mathrm{Zr}-95 \mathrm{Nb}, 103 \mathrm{Ru}$, and $141_{\mathrm{Ce}}$ continued to increase during the month of May in ground-level air in the northern hemisphere. The concentrations of these radionuclides were three fold higher than the concentrations measured in April. The concentrations are the highest measured since 1963. The 
radionuclide concentrations in the southern hemsphere have continued to decline since the French nuclear test series during the summer of 1968.

A procedure was developed to measure the concentrations of trace elements in rainwater utilizing contamination-free methods. Using this procedure the concentrations of $\mathrm{Na}, \mathrm{K}, \mathrm{Cl}, \mathrm{Br}, \mathrm{Zn}$, $\mathrm{Mn}, \mathrm{Cu}, \mathrm{As}, \mathrm{Sb}$, and $\mathrm{Ag}$ have been determined. The Ag concentration (l ppb) is an order of magnitude higher than the concentrations found in rlver water. These values are serving as a background for calculations and evaluations for the Northeast Colorado Hail Experiment Program.

55 Fe in the Human Population of the World - N. A. Wogman

Stable iron and 55Fe measurements from human blood obtalned from France, Italy, Spain, Gabon, Colombia, Nıgeria, and Brazil in 1969 are in excellent agreement with limited data from 1966 . The $196955 \mathrm{Fe}$ data, when corrected for half-life to 1966 results, do not show a correlation with human age. Investıgations of correlations of $55 \mathrm{Fe}$ activities independent of stable Fe are presently being completed as a possible means of detecting change with age and sex.

Sufficient data from throughout the world's populations have been analyzed to show a general trend in $55 \mathrm{Fe}$ concentration. Data analyses indlcate that the most probable location for high $55 \mathrm{Fe}$ levels in human blood 15 in the region from $29^{\circ}-40^{\circ} \mathrm{N}$ lat. This includes some of the islands of Japan. The maximum in the southern hemisphere is about $30^{\circ} \mathrm{S}$ with a range of $25^{\circ}-32^{\circ} \mathrm{S}$, which indlcates that the areas of New Zealand, as well as Australla and portions of Brazll, should have high 55 Fe concentrations. The program is being expanded to include samples from the geographical areas having the specific maximum and minimum concentrations.

Radioanalytical Methods and Evaluation - N. A. Wogman

The retention efficiency of radionuclides from natural waters on fine mesh ion exchange and sorption beds was completed for nine of the long-lived fission-produced and columbia River radionuclides. For this investigation, linear flow rates of $75 \mathrm{~cm} / \mathrm{min}$ and $1 \mathrm{~cm}$ thick beds of $\mathrm{Al}_{2} \mathrm{O}_{3}, \mathrm{SnCl}_{2}$-activated $\mathrm{Al}_{2} \mathrm{O}_{3}$, $\mathrm{BaSO}_{4}$-activated $\mathrm{A}_{2} \mathrm{O}_{3}$, and 400 mesh DOWEX anlon and cation resins were employed. For fresh water, the ion exchange beds provide quantitative retention of the lonic species; however, they are not suitable for the saline waters. The Snci2activated $\mathrm{Al}_{2} \mathrm{O}_{3}$ beds provide nearly quanticatıve retention for ${ }^{5} 1_{C r}$ from seawater and improve the retention of $\mathrm{Sb}$ radiolsotopes but have a somewhat lower retention efflciency for the other radioisotopes than the normal $\mathrm{Al}_{2} \mathrm{O}_{3}$. The $\mathrm{BaSO}_{4}$-activated $\mathrm{Al}_{2} \mathrm{O}_{3}$ 
reduced the retention efficiency of all of the radionuclides studied except $\mathrm{Ba}$ and $\mathrm{Ra}$ radioisotopes. It thus appears that. it will be necessary to use at least two sorption beds for the

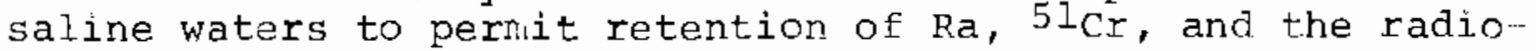
nuclide group normally retained on the $\mathrm{Al}_{2} \mathrm{O}_{3}$ beds.

\section{Precipitation Scavenging}

In-Cloud Scavenging - C. E. FIderkin

Tracer materials are required for studies of precipitation scavenging and atmospheric transport and diffusion. For this work, particles of submicron sizes are particularly desirable but difficult to generate. A method presently being investigated which may be extremely useful is the exploding wire particle generation techniquo. The earlier generators have been designed to vaporize wires of about 0.2 gram. A generating system is presently being designed for exploding wires of I gram or larger with the final objective of using these generators for ground base work in below-cloud scavenging, aircraft mounted for in-cloud scavenging, and for large-scale atmos. pheric mixing studies.

Other effort emphasized development of a system for the simulation of cloud air for testing the laboratory mockup of the prototype aircraft in-cloud sampler. The system consists of a water-saturated air filter to increase the humidity and a collision atomizer to produce water droplets.

Tests will be conducted, when the cloud air simulator is completed, to determine the operating conditions necessary for droplet evaporation and the degree of particle deposition ahead of the filter.

Below Cloud Scavenging - C. F. Elderkin

Washout coefficients were calculated for two field experiments which utilized sulfur dioxide as tracer. The values for experiment UIJ-16 with rainfall intensity of $2.8 \mathrm{~mm} \mathrm{hr^{-1 }}$ are $2.3 \times 10^{-5} \mathrm{sec}^{-1}$ and $5.0 \times 10^{-5} \mathrm{sec}^{-1}$ for sampler arc radii of 50 and 100 feet, respectively. Experiment UIL-17, rainfallintensity $3.7 \mathrm{~mm} \mathrm{hr}^{-1}$, led to coefficients of $3.0 \times 10^{-5} \mathrm{sec}^{-1}$ and $12.5 \times 10^{-5} \mathrm{sec}^{-1}$. Masses of $\mathrm{SO}_{2}$ recovered for analysis approached the lower limit of detection by the modified west and Gaeke method. The resulting coefficients are about onefourth of those predicted by theoretical calculations based on the measured raindrop size spectra and a collection efficiency which is dependent only upon the diffusivity of $\mathrm{SO}_{2}$ in the air film. Several conditions have been identified which may have contributed to a deficiency of mass of $\mathrm{SO}_{2}$ recovered, and these are under study. 


\section{Diffusion and Turbulence}

Transport and Diffusion - E. C. Watson

Emphasis was directed toward preparation of results of $85 \mathrm{Kr}$ releases for publication. The draft describes the system, its potential application, and glves some sample analyses from a continuous and a puff release. Among the analyses included in the draft are a compilation of $\sigma_{x}$ and $\sigma_{y}$ for a puff of $85 \mathrm{Kr}$ released during slightly stable atmospheric conditions. At $200 \mathrm{~m}$ from the source, $\sigma_{\mathrm{x}}$ was $44 \mathrm{~m}$, and at $800 \mathrm{~m}$ distance it was $153 \mathrm{~m}$. oy values at 200 and $800 \mathrm{~m}$, respectlvely, were $12 \mathrm{~m}$ and $39 \mathrm{~m}$. Ratios of $\sigma_{y}$ to $o_{x}$ of 3.7 at $200 \mathrm{~m}$ and 3.9 at $800 \mathrm{~m}$ indicate the continuing elongation of the puff.

Compilation of raw $85 \mathrm{Kr}$ concentrations with time and of accompanying meteorological data 15 underway.

\section{Radioisotopes as Particles and volatiles}

Turbulent Deposition - L. C. Schwendıman

Particle generation and sampling problems in the wind tunnel deposition study received sustalned attention. There has been strong motivation toward using wires of different diameters as Impactors to determine particle profiles because of the inherent simplicity of sampling and the potential offered for measuring particle concentration profiles near the deposition surface with a minimum of air disturbance. Although these desirable qualities are needed, it appears that variables not earlier considered are introduclng uncertainties which must be resolved. Improvements in reproducibility were achieved by isolating the wires from supports which were vibrating with the tunnel movement. The monodispersity of particles introduced is important in evaluating airborne concentrations and extra precautions were taken to insure that the sample results were not biased by a few large particles. These measures permitted reproducibility of , $10 \%$ to be achieved when 6 i particles were sampled with a 0.036 inch wire. Improved reproducibility is desirable. Accuracy of the 0.036 inch wire sampling appears adequate for the velocity used. When compared with an isokinetically obtained sample, the impactor sample yielded a concentration which was 98 of of the filter-collected sample.

\section{BOMEX STUDIES}

\section{Meteorological Flux Measurements - C. E. Elderkin}

Meteorological measurements from the TRITON buoy during the second BOMEX period were limited by heavy seas which prevented regular servicing of the buoy. One magnetic tape of data 
was recorded and recovered hefore waves, hreaking over the buoy, leaked water into the electronics compartment and placed the data digitizer out of commission for the romainder of the second period. Repairs have been effected and third-period neasurements with recordings of three wind components from the gill anemometer and of wet and dry bulb temperature are planned.

$$
\text { Precipitation Characteristics - C. E. Elderkin }
$$

During Phase II of BOMEX (May 24-June 9), raindrop size and electric charge measurements were made aboard the USC\&GSS Discoverer at station ECHO, approximately $550 \mathrm{kilometers} \mathrm{east}$ of Barbados. The bulk of the electric charge data was collected during a two-hour period of rain (total gaged rainfall was 1.07 inches) on June 8. Precipitation at other times was brlef and of light intensity, but complete records of charges and several raindrop-size samples were collected during these showers. Analysis of the data is beginning and comparisons with meteorological radar and surface observations, radiosoundings and atmospheric electrical parameter measurements collected by other BOMEX participants are expected as these data are made available.

\section{Fallout Characteristics - N. A. Wocman}

During the period from May 1 to May 28, 1969, air, water, and rain samples were collected aboard the $R / V$ FLIp while sta.. tioned in the BOMEX array. Water samples were collected at the surface and at depths of $10,20,35,50,65$, and 88 meters. Air samples were collected at elevations of $0.3,2.4,4.9,7.9$, and 17.4 meters above the sea surface. A few of the vertical air profiles from the R/V FLIP and Rockaway show increasing radionuclide concentrations with increasing helghts. The seawater samples from Rockaway show little variation in $7 \mathrm{Be}$ concentrations from the surface to a depth of 30 meters. Below 30 meters the concentration decreases rapidly. Measurable 7Be concentrations were detected at 100 meters but not at or below 150 meters. The $7 \mathrm{Be}$ concentrations between 0 and 20 meters varied considerably with time. The concentrations generally decreased throughout period I. The latter concentrations in the last layer may have been abnormally increased just prior to the first period because of the increased transfer across the sea surface from variable atmospheric conditions prior to Period I. Wind speeds were noted prior to Period I in the range of 40 knots. Winds were generally 5 to 15 knots throughout Period I at both the Rockaway and FLIP locations. 
BNWL- 1149

RADIOLOGICAL AND HEALTH PHYSICS

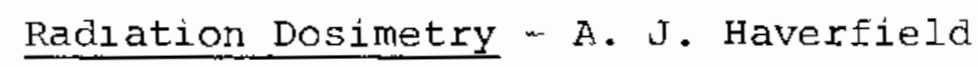

Computer analysis of the Glass-Braby cylindrical site data continued. A cubic interpolation subroutine for obtaining curves for intermediate beam position was completed. We have been trying to find a rationai way to subtract from their data the counts arising from amplifier noise. Until recently, no very appealing method for identıfying noise had turned up. Now, however, we find that a plot of

$$
\Delta{ }^{2} \mathrm{~N}(\Delta) \quad \text { vs } \quad \log \Delta
$$

guves a double-peaked curve and we are falrly sure that one of the peaks is due almost solely to amplifler noise.

A source of low energy characteristic $X$ rays is required for counter calibration. Several configurations have been tried, and we are not convinced that a useful source of characteristic aluminum $X$ rays cannot be obtained by alpha-particle bombardment or excitation by $x$ rays of slightiy greater energies. A proportional counter was tested with $x$ rays excited by low energy electrons and then exposed to the other two possible sources while belng operated at the same voltage and pressure. No $X$ rays were detected. Another possible source of $X$ rays for calibration is from higher energy electrons penetrating a thin target. In this case, the characteristic lines should stand out above a broad continuum of bremsstrahlung. The $30 \mathrm{keV}$ electron source for measuring electron path characteristics may be useful as a gun for this type of source.

A sample of polystyrene containing 20 percent carbon was used as a calorimetric sample for chemical reaction studies. For the first time, the measurements indicated that an exothermic reaction was taking place in the sample when bombarded with $1.7 \mathrm{MeV}$ protons. The measurement gave a net exothermic result of about 0.8 to 0.9 percent relative to aluminum. When the measurement on pure polystyrene conducted last month is considered (approximately 0.1 percent endothermic), it appears that the addition of 20 percent carbon to the polystyrene adds about 1 percent to the thermal energy measured in polystyrene during proton irradiation.

Some data taken on the first day of the run appear to be inconsistent with the rest. The data indicated that the exothermic effect was approaching 1.5 percent. The next day, the results dropped back to 0.8 and 0.9 percent. This discrepancy appears to fall outside the error limit for the calorimeter which is normally well under" 0.1 percent and may indlcate that 
the plastic recovered somewhat during the intervening hours. Similar hehavior, however, was not observed on subsequent irradiations.

$$
\text { Radiation Physics - D. J. Haverfield }
$$

In order to extract useful information from fluorescence rise times, it is necessary to determine accurately the system response function. This response must be unfolded from the observed fluorescence to yield energy transfer rates associated with optically excited states. Our present resolution of approximately 1 nanosecond (FWHM), appears to be phototube limited. And for this reason, we are thoroughly investigating the factors involved in the single photon timing. These include time dispersion due to photoelectrons emitted from different regions of the phototube and time pick-off methods. By confining the illumination to less than 0.6 inch from the photo. cathode center, the transit time spread can be kept below 0.1 nanosecond. This time dispersion increases to 0.5 nanosecond for full illumination of the photocathode. We have tried crossover timing and leading-edge timing and it appears that neither of these techniques is suitable for ultimate resolution. By applying a new technique of "constant fraction of pulse height trigger," we hope to reduce the phototube time jitter to less than 0.5 nanosecond.

A systematic study of the angular distribution of the electrons ejected from nitrogen by 1.0 MeV proton impact was started. A modification to a target cell and to the Faraday cup used for proton beam intensity measurements now makes possible the energy analysis of electrons ejected at angles between $10^{\circ}$ and $135^{\circ}$ with respect to the forward direction of the proton beam. This angular distribution study will be carried out at various proton energies and for various target gases as time permits.

By careful adjustment of the Helmholtz coils arrangement, and the addition of a small amount of magnetic shielding, the lower limit of the time-of-flight electron energy analysis has been extended to approximately $10 \mathrm{eV}$. These results for low energy electrons will complement the data being obtained by electrostatic analysis.

Nuclear Techniques in Medicine - A. J. Haverfield

The in vivo neutron activation analysis method for measuring total body calcium in humans was used on patients for the first time this month. Five patients whose total body calcium content is expected to change by at least 5 percent during the next few months were measured by this technique. Many more patients will be measured during the next few months and all of 
these measurements will be followed by a second measurement after an interval of a few months. This technique can detect and measure a change of 3 percent or more in total body calcium.

After approximately 12 patients have been measured, Battelle-Northwest research efforts will be directed toward the development of methods for other major elements in the body. Initial studies on total body phosphorus and nitrogen show that accurate measurements should be possible. A preliminary study is presently being made with mice to determine whether certain diseases in mice which cause a loss of phosphorus in bone also cause a change in the soft tissue phosphorus to potassium ratios. This ratio, if constant, will be used to differentiate between bone and soft tissue phosphorus.

Some preliminary measurements were made with the precision $59 \mathrm{Fe}$ whole-body counter to provide King county Hospital physicians with a better understanding of its capability. They plan to soon start iron loss and nutrition studies in 1 - to 6 -monthold infants using this counter.

\section{RADIATION INSTRUMENTATION}

Radiological Chemistry - N. A. Wogman

The high resolution of the Ge(Li) gammanray spectrometer has eliminated many of the previously required radiochemical separations; however, even with the large anticoincidence shielded Ge(Li) diodes, there are many radionuclide mixtures which require some chemical separation for their analysis. A technique modification which could greatly improve the resolving power of Ge(Li) spectroscopy but which would not unreasonably increase the volume of data obtained per analysis is "Sum Coincidence Spectroscopy." A system has been designed which will employ two 15 percent Ge(Li) diodes in an anticoincidence shield. [The percentage is the efficiency relative to a 3 -inch by 3-inch NaI(Tl) detector at $25 \mathrm{~cm}$.l Four spectra - a single photon spectrum, a sum coincidence spectrum and coincidence spectra of each of these with the anticoincidence shield - will be obtained. Considerations based on the radionuclide mixtures which require analysis for Division of Biology and Medicine problems indlcate that this instrumental method will provide a major improvement in high-sensitivity, nondestructlve radionuclide analysis. The system design will requlre 8,000 channels of storage capacity for its complete utilization. 


\section{DISTRIBUTION}

13

1
Atomic Energy Commission, Washington, D. C. Division of Biology and Medicine

N. F. Barr

H. D. Bruner

W. W. Burr

J. J. Davis

C. W. Edington

$\mathrm{J}$. Z. Holland

R. H. Huebner

J. S. Kirby $-\mathrm{Smith}$

S. Allan Lough

W. F. Marlow

J. R. Totter

J. N. Wolfe

R. W. Wood

Division of Space Nuclear Systems

J. A. Powers

Division of Technical Information Extension

Richland Operations office

H, E. Parker

C. L. Robinson

D. G. Williams

Savannah River Operations office

R. Beyers

Argonne National Iaboratory

P. F. Gustafson

$\mathrm{J}$. Kline

J. Loeding

Brookhaven National Laboratory

G. M. Woodwell

Oak Ridge National Laboratory

S. I. Auerbach

Laboratory of Radiation Biology, UCLA

A. Wallace 
Atlantic Rlchfield Hanford Company

R. E. Tomlinson

Douglas United Nuclear

Hanford Environmental Health Foundation - Library

E. L. Alpen

W. J. Bair

C. A. Bennett

J. J. Cadwe 11

L. A. Carter

W. J. Clarke (2)

J. P. Corley

G. J. Dau

F. G. Dawson

D. R. de Halas

W. L. Dotson

C. E. Elderkin

S. J. Farmer

R. F. Foster

J. J. Fuquay

W. A. Haney

H. Harty

A. J. Haverfield

J. F. Honstead

F. P. Hungate

J. L. Jaech

R. L. Junkins

D. R. Kalkwarf

L. J. Kirby

H. A. Kornberg

H. V. Larson

K. H. Larson

W. H. Matchett (2)

D. B. Menzel (2)

R. E. Nakatani

C. E. Newton, Jr.

J. M. Nielsen

T. P. O'Farrell

J. F. Park (2)

H. M. Parker

D. W. Pearce

R. W. Perkins

E. H. Phinney

N. S. Porter

K. R. Price

W. D. Richmond 
W. C. Roesch

L. C. Schmid

L. C. Schwendiman

A. J. Scott

C. L. Simpson

R. J. Sorenson

W. G. Spear

M. F. Sullivan (2)

W. L. Templeton

R. C. Thompson

C. R. Tipton, Jr.

C. M. Unruh

E. E. Voiland

E. C. Watson

W. E. Wilson

N. A. Wogman

D. C. Worlton

Patent Section (2)

Technical Information Files (2)

Technical Publications (2) 

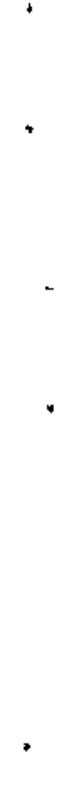